\title{
The Social Philosophy of Herbert Hoover*
}

\author{
GeORGE H. NASH
}

\begin{abstract}
O f the several hundred million people who have lived on the North American continent since the days of the Pilgrims, only thirty-eight have become president of the United States. What do we think of when we hear the name of one of these men, Herbert Hoover? What images arise? What aspects of his long life spring to our consciousness?

All of us, no doubt, automatically associate him with the Great Depression of the 1930s; it was Hoover's personal misfortune to preside over the nation when the Great Bull Market spluttered and collapsed in October 1929. Some of us may have recollections of an elderly man addressing Republican national conventions in 1952, 1956, or 1960-sentimental occasions when throngs of men and women cheered a seemingly quaint figure from a seemingly distant past. Some may know that Herbert Hoover was the first president born west of the Mississippi River or that he was the man who appeared in the first public demonstration of television in 1927. Some may be aware of his

*This essay is one of several submitted by various historians to Senator Mark Hatfield of Oregon in 1979 for insertion in the Congressional Record to commemorate the fiftieth anniversary of President Hoover's inauguration. The general theme of the essays was "Herbert Hoover Reassessed."
\end{abstract}


Quaker upbringing and of his enormous humanitarian relief work in Europe during and after World War I. Five years ago, Aleksandr Solzhenitsyn remarked that the American Relief Administration under Herbert Hoover's direction saved the lives of literally millions of Russians during the great famine of 1921 to 1923. Indeed, at the height of this massive relief effort-which was but one of many programs of the ARA after the First World War-Hoover's organization fed fifteen million Russian men, women, and children a day.

Even this summary does not encompass Hoover's interests and achievements. As a mining engineer and multinational businessman, for example, with gigantic and far-flung enterprises from the late 1890s to World War I, he traveled around the globe five times before 1914-five times, that is, before the advent of the airplane. In all, he spent more than two years of his life on ships at sea. Later, in the 1920s, when he served in the cabinets of Presidents Harding and Coolidge, it was said that Hoover was secretary of commerce and under-secretary of every other department. After his four years in the White House he lived longer as an ex-president ( $311 / 2$ years) than any other former president in our history. Those of us who have visited Palo Alto, California and West Branch, Iowa can immediately point to two of his most visible benefactions, the Hoover Institution and the Herbert Hoover Presidential Library. When Hoover died in 1964, he had lived ninety extraordinarily productive years, including a full fifty in public service. Few American careers have been as multifaceted and remarkable as his.

What is significant for us today about the life of this man? If our parents or grandparents were asked this question, they might readily answer by quoting from a poem by Longfellow which school children of yesteryear used to learn:

Lives of great men all remind us We can make our lives sublime, And, departing, leave behind us Footprints on the sands of time. 
Certainly this is one reason why biographies of great men and women remain popular. We like to read about how others have coped with the adventures, challenges, and immutable realities of life.

But in the case of a figure like Herbert Hoover, our concern transcends the transient particularities of "human interest," fascinating though his life story is. For Hoover did not simply lead a career rich in accomplishment; he reflected on the circumstances which made such a career possible. Unlike most American men of affairs, who have been content to act on the public stage but not to meditate much about it, Hoover did not leave it to his biographers to extract some meaning from the kaleidoscopic events of a busy life. Instead, he developed and in his time came to personify a perception of America, a vision of America, a political and social philosophy which could explain the greatness of the country he loved-and, incidentally, the ground for his own achievements. It is in this vision and this philosophy that we can discover some of the enduring significance of Herbert Hoover.

\section{$\mathbf{H}$}

E WAS BORN in 1874 in the little Quaker community of West Branch, Iowa, the son of the village blacksmith. Before he was seven his father had died. His mother, a recorded minister in the Society of Friends, died a little over three years later, so that in early 1884, before he was ten, young Herbert, his brother and his sister were orphans. Hoover's brother Theodore in his autobiography wrote of the desolation that the children of Jesse and Hulda Hoover felt when their mother died: "The lady of the golden sunshine of little brown house had gone away, and there were left only three small children, adrift on the wreck of their little world."1

Despite these traumas, Herbert Hoover's later reminiscences of his Iowa childhood were gentle and almost idyllic. In the

\footnotetext{
${ }^{1}$ Theodore J. Hoover, "Memoranda: Being a Statement by an Engineer," typewritten manuscript, 1939, p. 35, Herbert Hoover Presidential Library, West Branch, Iowa.
} 
most famous of these recollections, first delivered in 1927, Hoover began:

I prefer to think of Iowa as I saw it through the eyes of a tenyear-old boy - and the eyes of all ten-year-old Iowa boys are or should be filled with the wonders of Iowa's streams and woods, of the mystery of growing crops. ${ }^{2}$

Hoover remembered the old swimming hole, the joys of fishing and hunting for game, the delights of his Aunt Millie's cooking, and other features of life in rural lowa. Of his native state he declared: "The good Lord originally made it the richest stretch of agricultural land that ever blessed any one sovereign government. It was populated by the more adventurous and the more courageous, who fought their way along the ever-extending frontier."

From Iowa in 1885 young Herbert Hoover was sent west to Oregon to live with the family of his uncle, Dr. Henry John Minthorn, the newly appointed superintendent of a Quaker academy (now George Fox College). Newberg, Oregon-said the 1886-1887 Catalogue of Friends' Pacific Academy-"is a temperance town, and has a moral and enterprising class of people. There are no saloons nearer than eight miles. ${ }^{4}$ It was in such a sturdy and upright environment that Hoover grew into his teens. From Newberg in the late 1880 s he traveled with his relatives to Salem, Oregon, where he became clerk and office boy for his Uncle John's Oregon Land Company, an enterprise which sold fertile soil to settlers in the Willamette Valley. One summer Hoover had a different job: weeding onions near Sherwood, Oregon for fifty cents a day plus board.

After nearly six years in Oregon, Hoover traveled down to California in 1891 to become a member of the entering, or Pioneer, class at newly-founded Stanford University. Here he soon became a campus leader, obtaining such positions as manager of the football team, president of the Geology Club,

${ }^{2}$ Herbert Hoover, "Boyhood in Iowa," Palimpsest 43 (August 1962): 337.

${ }^{3}$ Ibid., p. 344.

'Catalogue of Friends' Pacific Academy, 1886-1887, George Fox College, Newberg, Oregon, p. 13. 


\section{The Annals of Iowa}

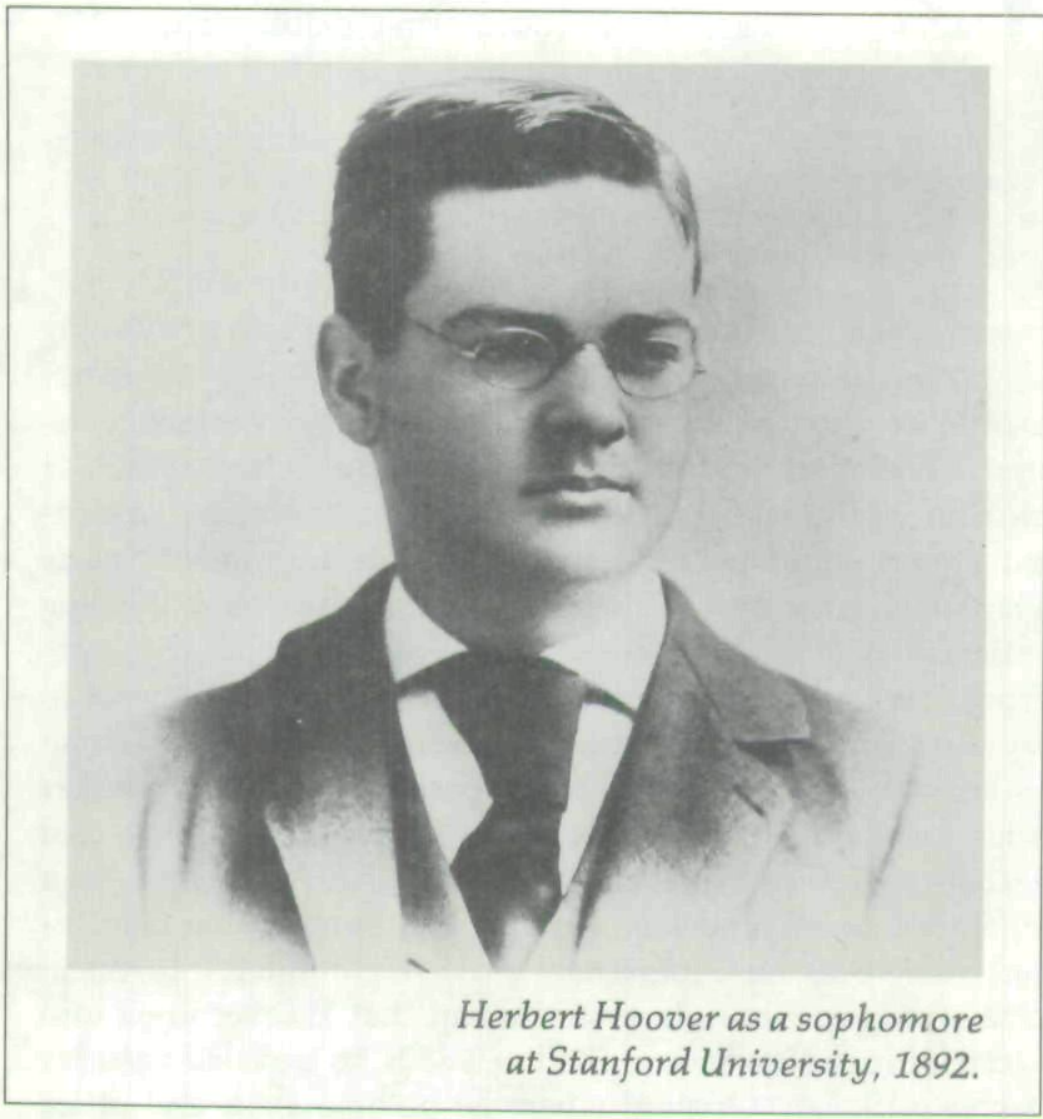

and student treasurer. After graduating in 1895, Hoover spent some time working in the mines of the Sierra Nevadas until, early in 1896, he obtained a position on the staff of an eminent San Francisco mining engineer, Louis Janin. A little over a year later a London firm cabled Janin asking him to recommend an American engineer for work in its mines in Western Australia. There was one stipulation: the man should be thirty-five. Herbert Hoover was not yet twenty-three. Janin decided to take a chance and recommended Hoover anyway. But he admonished his young assistant that he had better look thirty-five before he reached Australia. Hoover took his advice; he grew a beard. When he reached London en route to the land "down under," his British employer marvelled at how Americans were able to preserve their youth. 
Hoover's journey to London and then to Australia, via France, Italy, the Suez Canal, and India, must have been an intensely stimulating one to a young man of twenty-two. Years later, reflecting on this voyage, he remarked significantly, "History became a reality and America a contrast." ${ }^{5}$ It was Hoover's first exposure to the world outside the United States, and in his responses to it we find one of the principal sources of his later political and social philosophy.

Of all the places on earth where men have dug for gold, Western Australia in 1897 must have been the most desolate and remote. When Hoover disembarked on the coast of Australia that year, he headed inland nearly four hundred miles to the mining towns of Coolgardie and Kalgoorlie, deep in the inhospitable outback. Hoover's descriptions of life in this rugged land were vivid. "It's a country of red dust, black flies, and white heat," he wrote from Kalgoorlie to an Oregon friend, Burt Brown Barker. "I could not portray the misery of any one of them on paper. The country is an endless desert, no water, no nothing but mines. All water must be condensed-costs $\$ 63.25$ per 1000 gallons. The typhoid is rampant, there being an average of 3 deaths daily in this town (9000 people)."6 During the Australian summer, the daytime temperature might be 110 degrees in the shade, 150 degrees in the sun. It was a land to make one think of home. Writing to his cousin in August 1897, Hoover declared: "Am on my way back to Coolgardie. Am glad to get back within the borders of civilization. Coolgardie is three yards inside of it; Perth is about a mile, and of course San Francisco is the center. Anybody who envies me my salary can just take my next trip with me, and he will then be contented to be a bank clerk at $\$ 3$ a week for the rest of his life, just to live in the United States. Stanford is the best place in the world."7

In other letters home Hoover commented on the customs of the aborigines and the idiosyncrasies of his fellow men in the

${ }^{5}$ Herbert Hoover, Memoirs, vol. I, Years of Adventure, 1874-1920 (New York: Macmillan Co., 1952), p. 30.

'Hoover to Barker, 25 October 1897, Pre-Commerce Papers, Herbert Hoover Papers, Herbert Hoover Presidential Library, West Branch, Iowa (hereafter cited as HHP).

${ }^{7}$ Hoover to Harriette Miles, 5 August 1897, Pre-Commerce Papers, HHP. 
gold fields. "I have found out many things about Englishmen," he reported to a friend. "They are very particular about such things as dignity of position, social names, etc., etc. They are very distant and friendliness approaching familiarity is greatly abhorred. ..." He told Barker, "Yankees are not well received. They only have us because they have to. They don't know how to make their mines pay dividends. We do." ${ }^{\prime 8}$ In view of these sentiments, it is not surprising that Hoover acquired a nickname in Western Australia. H. C. were the initials of his first and middle names. H. C. Hoover. His friends said that "H. C." stood for "Hail Columbia."

In late 1898, after a successful stint as a manager of one of the greatest mines in Australian history, Hoover left the land down under for a new and more responsible mining position in China. On the way he stopped in California, married his college sweetheart, Lou Henry, and took her with him to a new home in the Orient. Once more Herbert Hoover, not yet twenty-five, found himself living among strangers and encountering a foreign civilization. Once more the process of sifting impressions and comparing the world outside with America proceeded.

At this point we can detect one of the threads of Herbert Hoover's early life. From the cornfields of Iowa to the orchards of Oregon, to the spacious acres of Stanford University, to the rugged Sierra Nevadas, to the dusty gold fields of Australia, even to the coal mines of northern China, we discern a repeated pattern: Herbert Hoover's early days were spent on or near frontiers. It is symbolically appropriate that he was a member of the Pioneer Class at Stanford. His was largely an outdoor life, lived in environments which rewarded initiative, industry, resourcefulness, and merit. Since the day when Hoover's SwissGerman ancestor, Andreas Huber, landed in Philadelphia from the Old World in 1738, the Hoover clan had moved gradually westward, until, with Herbert, the trek circled the globe. Benjamin Franklin is supposed to have said that America is a country where we ask of a man not "Who is he?" but "What can he do?". Hoover's was a society populated substantially by people who

${ }^{8}$ Hoover to Barker, 25 October 1897, Pre-Commerce Papers, HHP. 


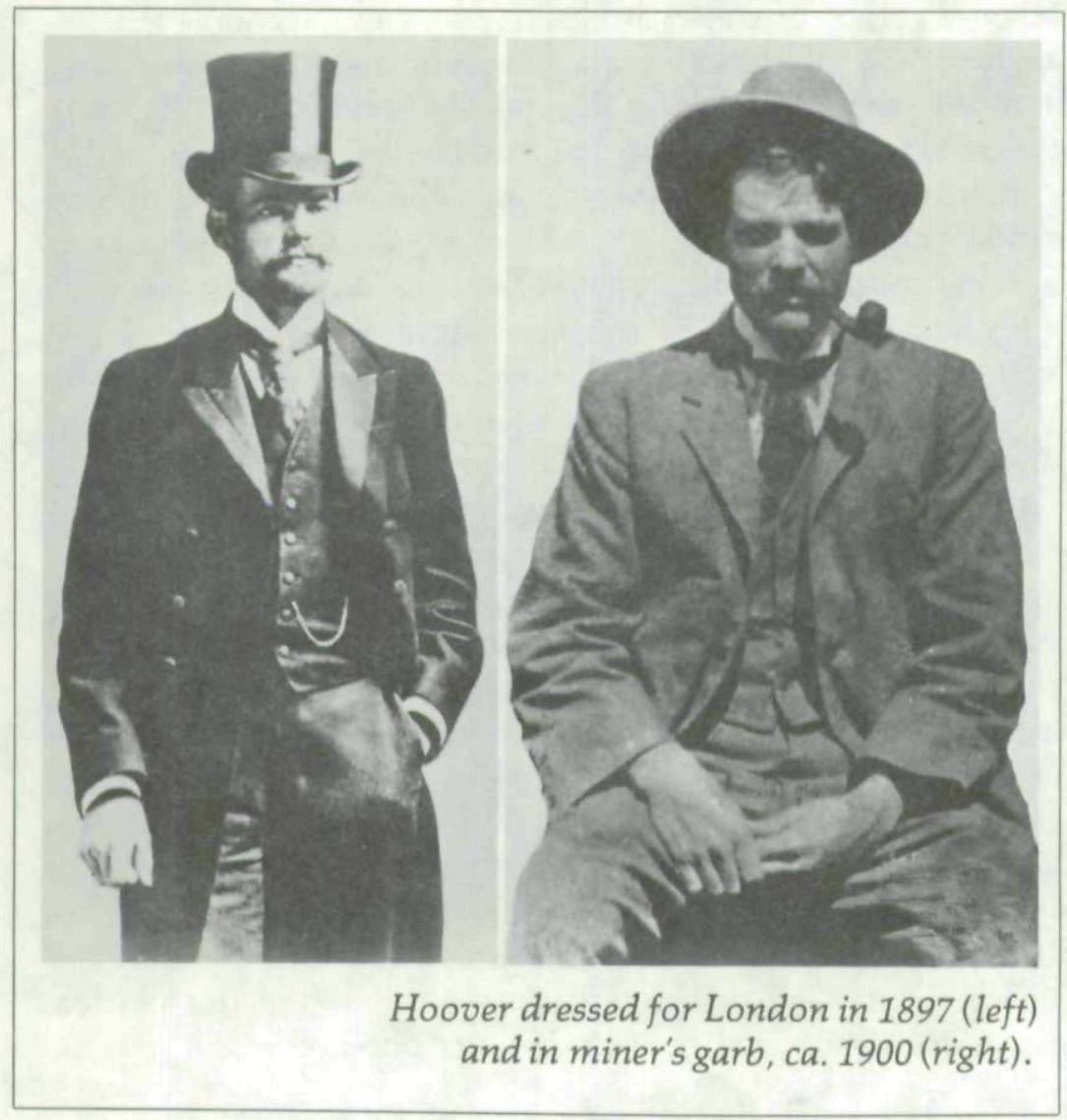

held this attitude and who had moved away from a constricted and stratified civilization.

In late 1901 Hoover left China for England and a partnership in an eminent firm of mining engineers. Until World War I, London, the mining and financial capital of the world, was his base of operations while he traveled continually, inspecting, financing, and developing mines from Burma to Australia, from South Africa to Siberia. For some Americans with similar careers and lifestyles, the temptation might have been irresistible to become an expatriate. For Herbert Hoover, if anything the opposite was true. Throughout these years abroad, his 
thoughts turned often toward his native land. His home in London became a mecca for American mining men, journalists, and Stanford graduates visiting Europe. As early as 1907 Hoover expressed to the president of Stanford University his longings to retire from his profession (he was only thirty-three) and to turn to a life of service in the United States. In 1912 he became a trustee-and an exceedingly active one- of Stanford University. In the summer of 1914 he was negotiating the purchase of the Sacramento Union in California when war interfered. Had it not done so, Hoover might have entered public service as a newspaper proprietor.

And all the while, Hoover was observing, analyzing, and evaluating the social systems of the Old World and the New. Long voyages at sea gave him an opportunity to read about the politics, economies, and cultures of countries all over the earth. It was, he later said, "a reeducation of myself" that compensated for the utilitarian emphasis of his formal studies at Stanford. ${ }^{9}$ On one of these ocean trips, a British lady asked him what his profession was. An engineer, he said. "Why," she exclaimed, "I thought you were a gentleman!"10 This anecdote, which Hoover later recounted in his Memoirs, epitomized his distaste for the class consciousness and social rigidities of Europe. From all of this he turned. In a revealing letter written to an American friend in 1912, Hoover observed:

The American is always an alien abroad. He never can assimilate, nor do other peoples ever accept him otherwise than as a foreigner.

His own heart is in his own country, and yet there is less and less of a niche for him when he returns. One feels that one should have built one's fortune in America, altho it might have been less imposing. Yet one would be among one's own people and the esteem one hopes to build among one's associates would not be wasted by leaving them behind to go home and build at it again.

I have got to that stage now where I am playing the game for the game's sake, as the counters don't interest me any longer. I

${ }^{9}$ Herbert Hoover, undated biographical statement, quoted in Craig Lloyd, Aggressive Introvert: Herbert Hoover and Public Relations Management, 1912-1932 (Columbus: Ohio State University Press, 1972), p. 15.

${ }^{10}$ Hoover, Years of Adventure, p. 132. 
am disgusted with myself when I think how much better off you people are who stuck by your own country and place. When you walk down the street you meet a hundred men who have a genuine pleasure in greeting you. I am an alien who gets a grin once in nine months. ${ }^{11}$

Two years later, the conflagration of World War I enveloped Europe and changed the course of Herbert Hoover's life. While giant European armies bogged down in the trenches Herbert Hoover, working without pay, directed the Commission for Relief in Belgium, a neutral organization which procured and distributed food to the civilian population of Belgium, caught between the German army of occupation and the British naval blockade. It was a noble undertaking which ultimately brought food to ten million people a day and which catapulted Hoover to worldwide fame as a humanitarian. One of the noteworthy themes of Hoover's correspondence as chairman of the CRB was that this largely American volunteer organization reflected American ideals. It was a source of pride to him that while Europeans fought and slaughtered one another, an American-led relief effort was saving the lives of noncombatants.

What was the effect of this experience upon Herbert Hoover? The more I study his three years in Europe from 1914 to 1917, as head of the Belgian Relief, the more surprising it seems that he ever endured the ordeal. For behind the uplifting routine of providing daily food to needy Belgians lay a depressing world of conspiracy, national rivalry, and festering intrigue. As early as December 1914, less than two months after he had assumed leadership of the CRB, Hoover observed with some incredulity:

The amount of small jealousy that exists around amongst the Belgians themselves and amongst Relief Committees and professional charity workers throughout the world, and the malice which they can all of them display at times is beyond belief. Were it not for the haunting picture in one's mind of all the long line of people standing outside the relief stations in Belgium, I would have thrown over the position long since. ${ }^{12}$

${ }^{11}$ Hoover to George J. Bancroft, 1912, Pre-Commerce Papers, HHP.

${ }^{12}$ Hoover to Josephine Bates, 10 December 1914, Commission for Relief in Belgium Papers, Hoover Institution, Stanford University, Palo Alto, California (hereafter cited as CRBP). 
From the day of its inception the CRB had to cope with critics in the various belligerent governments who were convinced that this unprecedented humanitarian work was enhancing the military strength of one side or the other. Scarcely a month went by which did not witness some challenge to the continued existence of the CRB. Stories were circulated impugning Hoover's integrity; in England in 1916 an investigation of his leadership of the CRB was begun. Even some of the Belgian officials with whom Hoover worked conspired at one point to whittle down American influence, and there is reason to suspect that jealous Belgians spread rumors about allegedly dishonest conduct by Hoover while he was a mining engineer. Many times, weary from incessant conflicts with one belligerent power or another, Hoover contemplated and even threatened resignation. During one crisis in January 1916, he wrote to his friend Hugh Gibson that "the Commission is getting hammered from all sides. ... I I am free to confess that this business has gone on too long . . . . and I find staring me in my dreams a large poster entitled 'Go back to the lead mines,' in which occupation one obtains a modicum of human gratitude and a large liberty from hammers of all sizes. . . " ${ }^{13}$ Hoover, of course, did not quit, but from his disillusioning encounter with the emotions of war and the ancient antagonisms of Europe, he derived a lesson. On February 2, 1917 (one day after Germany resumed unrestricted submarine warfare) he told a friend:

If we have got to go into this war, I am extremely anxious that we should not go into it in alliance with anybody. . . . I dread the horrible entanglement of this country with all of the objectives of certain of the allies. . . . ${ }^{14}$

A few weeks later, the United States entered the war, and Hoover sailed back to America to direct our wartime Food Administration. But within two years he returned once more, this time to feed Europe while President Wilson and the Allies strove to draft a peace treaty at Versailles. From November 1918 to September 1919 Herbert Hoover crisscrossed Europe as

${ }^{13}$ Hoover to Gibson, 25 January 1916, CRBP.

${ }^{14}$ Hoover to William C. Edgar, 2 February 1917, CRBP. 


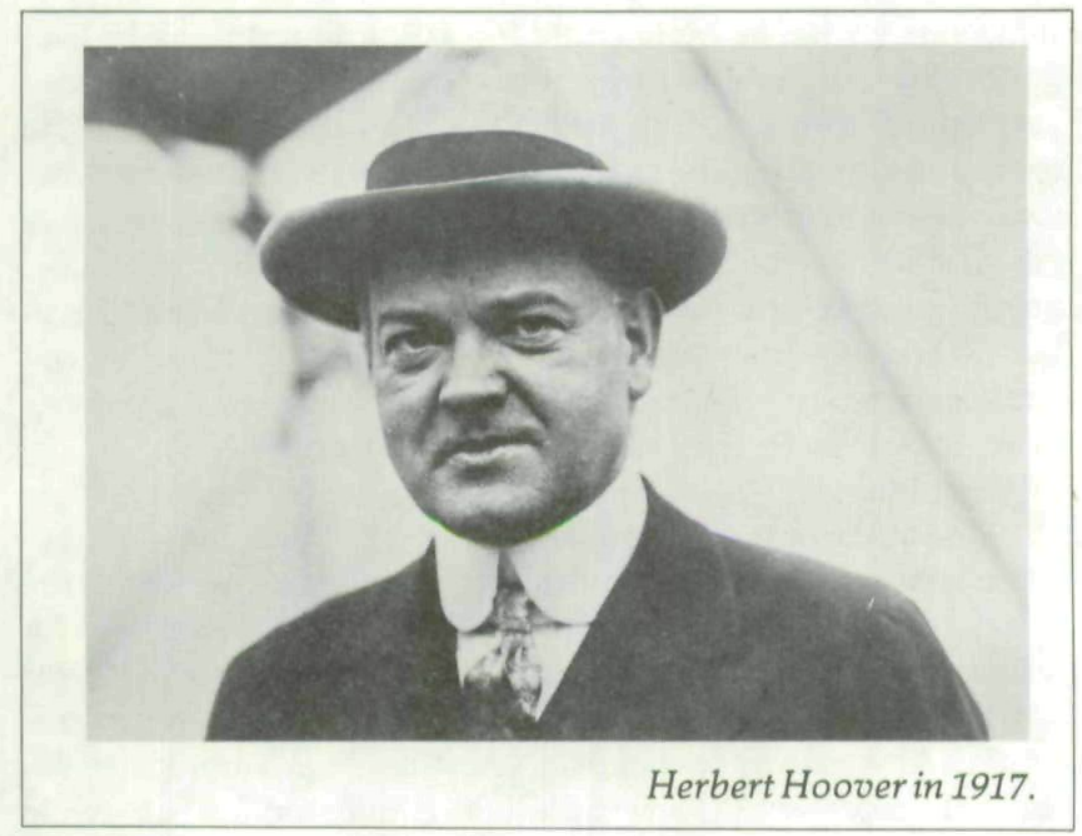

director-general of the American Relief Administration, organizing the supply of food for starving millions and facilitating the emergence of stable economies. The year 1919 was one of the most turbulent of our century; it was also one of the pinnacles of Herbert Hoover's life. Food had helped to win the war. Now, he believed, it must win the peace. The grim alternative was chaos, famine, a new generation of embittered Europeans, and the possibility of Communist revolution over much of the continent. Thanks in considerable measure to the herculean efforts of Hoover and his staff, perhaps one-third of the population of postwar Europe, including Russia, was saved from famine and death.

But if Hoover could take comfort from his outstanding humanitarian accomplishment in postwar Europe, there was much that he saw which profoundly alarmed him and helped to determine his future political and social thought. Although Hoover at this point was hardly naive, he was stunned and 
sickened by what he experienced in 1919. I do not think he ever got over it. For months an angry and frustrated Hoover pleaded and argued with the Allies to lift the blockade on the defeated enemy and to allow the currents of peaceful exchange to flow. Only after a long struggle did he attain this objective. Every day Hoover witnessed the profusion of national rivalry, jealousy, greed, myopia, and desire for revenge. Writing to John Maynard Keynes in June 1919, Hoover said, "I am completing my work in a few weeks and I shall leave Europe with a heavier heart than even in the worst days of the war."15

When Hoover finally returned to the United States in late 1919, he vigorously supported the Treaty of Versailles-not because he was an innocent idealist, nor because he considered the treaty perfect (he did not), but primarily because he deemed a settlement essential to a worldwide recovery from war. Hoover was not an irreconcilable like Senator Hiram Johnson of California. And yet, as he later observed in his Memoirs, he did leave Europe with "one absolute conviction": that while America could win wars, "it could not make lasting peace." To Hoover it now seemed that "irreconcilable conflicts" in ideals and experience separated the Old World from the New. "The two worlds were indeed strangers to each other," he declared. ${ }^{16}$ The New World, he came to believe, was remote from the imperialism, fanatic ideologies, racial antipathies, dictatorships, power politics, and class stratifications of Europe. As he expressed it in his Memoirs, "the forces which lay behind the rejection of American ideas at Paris [in 1929] were far deeper than the intrigues of diplomacy or the foibles of European statesmen. Here was the collision of civilizations that had grown three hundred years apart." 17

In 1921 Herbert Hoover became secretary of commerce of the United States; in 1928 he was elected president. Of the thirtyeight men who have occupied the Oval Office, Herbert Hoover undoubtedly enjoyed more extensive acquaintance with foreign

\footnotetext{
${ }^{15}$ Hoover to Keynes, 7 June 1919, Lord Keynes Papers, The Marshall Library, Cambridge, England.

${ }^{16}$ Hoover, Years of Adventure, p. 473.

${ }^{17}$ Ibid., p. 479.
} 
peoples and their social systems than any of his predecessors or successors. In another respect, too, he was unusual: he attempted to distill from his unique experiences a coherent understanding of the American experiment that he cherished. Few of our presidents have ventured self-consciously into the realm of political philosophy. Herbert Hoover did.

$\mathbf{H}$ IS FIRST systematic effort in this field appeared in 1922: a little book entitled American Individualism. ${ }^{18}$ This work represents the crystallization of the attitudes and perceptions which I have been describing in this essay. According to Hoover, the revolutionary upheavals of World War I and its aftermath had produced a world in ferment. In this cauldron several ideologies (he called them "social philosophies") were competing for the minds of men, among them Communism, Socialism, and Syndicalism. To Hoover, who had seen the vicious results that emanate from a blending of "bestial instincts" with idealistic humanitarian jargon, the need for a definition of the American system was urgent. He called this system "American Individualism."

By this term he definitely did not mean unfettered, oldfashioned laissez-faire, as he explicitly emphasized in the book. Hoover was anxious that individual initiative always be stimulated and rewarded, but it must, he said, be "tempered" by "that firm and fixed ideal of American individualism - an equality of opportunity. "19 Equality of opportunity, "the demand for a fair chance as the basis of American life," in Hoover's words, was "our most precious social ideal." 20 Hoover insisted that equal opportunity and a "fair chance" for individuals to develop their abilities were "the sole source of progress" and the principal impulse behind American civilization for three centuries. The American pioneer, he asserted, exemplified this spirit.

\footnotetext{
${ }^{18}$ Herbert Hoover, American Individualism (New York: Doubleday, Page \& Company, 1922).

${ }^{19}$ Ibid., p. $8 f$.

${ }^{20}$ Herbert Hoover, Commencement Address at William Penn College, Oskaloosa, Iowa, June 12, 1925, Penn College Bulletin, n.s. 19(July 1925).
} 
Hoover did not believe that equality of opportunity was automatically self-sustaining in a modern, technological economy. A certain measure of governmental regulation and guidance, some governmental legislation (such as anti-trust laws), were necessary, he felt, to prevent economic autocracy, inequality of opportunity, and the throttling of individual initiative. (Just two years before, in 1920, Hoover had labeled himself an "independent progressive." ${ }^{21}$ To Hoover it was imperative that "we keep the social solution free from frozen strata of classes. "22 But the nature and extent of this governmental involvement must be carefully defined and, above all, kept consistent with the broad American traditions of voluntary cooperation, local selfgovernment, and individual initiative. While not unmindful of the faults of unchecked capitalism, Hoover was an uncompromising foe of socialism and the totalitarian state.

Hoover's apotheosis of the United States as a land dedicated to the ideals of equal opportunity and freedom to carve one's own destiny won the assent of another distinguished American in 1923. Professor Frederick Jackson Turner, exponent of the famous "frontier thesis," was enthusiastic about Hoover's "meaty little book." "It contains," said Turner, "the New and Old Testament of the American gospel and I wish it a wide circulation." 23 Perhaps it is not coincidental that when Turner's book, The Frontier in American History, was published in 1920, he had given a copy to Hoover, who read it (according to his secretary) "with very great interest." 24

Twelve years after the publication of American Individualism the world had drastically altered. By then Herbert Hoover was an ex-president, and something called the New Deal was abroad in the land. Once again Hoover took up his pen, this time to write The Challenge to Liberty, a powerful critique of statist ideologies and a reaffirmation of the unique social philosophy

${ }^{21}$ Hoover to Ralph Arnold, 8 March 1920, Pre-Commerce Papers, HHP.

${ }^{22}$ Hoover, American Individualism, p. 9.

${ }^{23}$ Turner to Richard S. Emmet (one of Hoover's secretaries), 18 January 1923, Commerce Papers, HHP.

${ }^{24}$ Emmet to Turner, 27 January 1923, Commerce Papers, HHP. 
of America, "one of the last few strongholds of human freedom. ${ }^{25}$ Political theorists who examine this book might term it an expression of modified classical liberalism. But whatever the label, it articulated a philosophy forged in the aftermath of World War I which Hoover expounded, often with eloquence, for the rest of his life. Speaking before a Boys' Club in 1940, for example, he interpreted his version of the American Dream:

By a classless America our forefathers meant far more than a sociological expression. There were to be no stratifications in life that handicapped the rise of any boy from the bottom to the top. The human particles should move freely in the social solution. ... This idea of a fluid classless society was unique in the world. It was the point at which our social structure departed from all others. ${ }^{26}$

And always he drew the contrast between the America he loved and the Old World with its pestilent ideologies. Listen to his words at his birthplace in Iowa in 1948:

I have seen the squalor of Asia, the frozen class barriers of Europe. And I was not a tourist. I was associated in their working lives and problems. I had to deal with their social systems and their governments. And outstanding everywhere to these great masses of people there was a hallowed word-America. To them, it was the hope of the world.

My every frequent homecoming has been a reaffirmation of the glory of America. Each time my soul was washed by the relief from grinding poverty of other nations, by the greater kindliness and frankness which comes from the acceptance of equality and a belief in wide-open opportunity to all who want a chance. It is more than that. It is a land of self-respect born alone of free men and women. ${ }^{27}$

${ }^{25}$ Herbert Hoover, The Challenge to Liberty (New York: Charles Scribner's Sons, 1934), p. 48.

${ }^{26}$ Herbert Hoover, Further Addresses upon the American Road, 1938-1940

(New York: Charles Scribner's Sons, 1940), p. 221.

${ }^{27}$ Herbert Hoover, Addresses upon the American Road, 1945-1948 (New York: Charles Scribner's Sons, 1949), p. 77. 
How, though, could social fluidity and equality of opportunity be preserved? For Hoover there were many answers. One, perhaps the most crucial, was our educational system; another was governmental action to curb domination of the economy by clusters of economic power. Another (and this may seem surprising) was inheritance taxes; Hoover contended that "the sons of the successful [should] not by any mere right of birth or favor continue to occupy their fathers' places of power against the rise of a new generation in process of coming up from the bottom." ${ }^{28}$ Still another mechanism in Hoover's eyes was the Boys' Club movement; in it, he claimed, "there is a restoration of equal opportunity with all the other boys." 29 Indeed, many of Herbert Hoover's governmental policies and charitable activities over the years, including his long concern with child welfare, acquire a kind of thematic unity if we perceive them as attempts to promote equality of opportunity for all Americans, especially the young.

It was part of Herbert Hoover's ordeal in his later, postpresidential years that the political philosophy he developed, the vision of America that he expressed, came to seem abstract and anachronistic for many Americans. It was all right for Hoover to extol the social system that had produced him, many people seem to think, but were his paeans to America's traditional values relevant to the steelworkers of Pittsburgh, the tenant farmers of Mississippi, or the Okies of the Dust Bowl? Were American abundance and prosperity simply accidents of history, the products of a continent of free land? Wasn't the frontier gone now? Wasn't America's pioneer past over, and with it the supposedly outmoded Turnerian (and Hooverian) values of individualism, neighborly cooperation, and private initiative?

Herbert Hoover responded forcefully to such criticisms. It was not the mere availability of abundant land and natural resources that had blessed America, he insisted. It was a social system, animated by ideals. The "most potent force in society,"

${ }^{28}$ Hoover, American Individualism, p. 20.

${ }^{29}$ Hoover, Further Addresses, p. 222. 
he wrote, "is its ideals." ${ }^{30}$ To Hoover the principles of American Individualism were not anemic platitudes, to be uttered, perhaps, on the Fourth of July. Nor had America become a closed, stagnant society, and Hoover hoped that it never would. New frontiers of science, invention, and human welfare were just beginning to open exciting vistas of opportunity. Hoover warned against the contrary opinion (again fashionable today):

When we concede that progress is ended we concede that hope and new opportunity have departed. That is the concept of a static nation. It is necessarily the philosophy of decadence. No society can become static, it must go forward or back. . . . No society will function without confidence in its future opportunities. $^{31}$

\section{To} trievably outmoded, that he was, at most, a transitional figure to a world which has forever abandoned his values and his vision. Certainly it is true that America and the very nature of its government have altered since the days, a half century ago, when Hoover was president. When Hoover left the White House in 1933, the federal government's budget was less than five billion dollars. Today it is a hundred times higher. Since 1900 public spending in the United States has increased more than 239 times. Every year the federal deficit alone is several times greater than the entire federal budget during Hoover's years as chief executive.

And yet I suggest that there is today an increasing resonance to Herbert Hoover's philosophy, more than a decade after his death. In the current worldwide debate over "human rights" we hear echoes of Hoover's belief in the uniqueness of the American experiment and the superiority of a social system invigorated by the ideal of human freedom. Furthermore, the challenges we confront raise philosophical questions to which Hoover's answers deserve our attention.

${ }^{30}$ Hoover, American Individualism, p. 16.

${ }^{31}$ Hoover, Challenge to Liberty, p. 148. 
Consider, for instance, the increasingly pervasive, and legally countenanced, use of quotas in the hiring of men and women for jobs in business, universities, and government. In our commendable desire to eliminate past discrimination, are we not perhaps invoking an antithetic creed, which measures us by the crude and irrelevant categories of race, gender, and ethnic origin? Herbert Hoover's philosophy has much to say on this point.

Or consider the much-discussed "energy crisis." If Herbert Hoover were living today, I suspect that as a lifelong champion of efficiency and the elimination of waste he would vigorously encourage efforts towards conservation of our resources. But he would also stress that a far more precious resource than oil must not be allowed to atrophy. This is our social energy. And the source of this liberating social energy is not an overweening, coercive, stultifying, bureaucratic government but free men and women, uncommon men and women, competing and cooperating voluntarily in an open, fluid society. It is a proper function of government, I think he would say, to stimulate initiative and to foster its harmonious use, not to supplant private initiative or monopolize social energy.

Finally, I have emphasized in this essay the roots of Herbert Hoover's philosophy in the contrast he perceived between the Old World and the New. In evaluating his American Individualism we would do well to ponder anew the ghastly practical consequences of some of the alternative social philosophies which have motivated men and women in this often bloody century. Consider the tens of millions who have perished in the Gulag Archipelago. Consider the death camps at Auschwitz. Consider, today, the agony of the Vietnamese boat people.

Free societies, such as the one we today enjoy, are a rarity in human history, and they are not self-sustaining. To survive they require a cogent understanding of their fundamental, undergirding values and their antitheses. This Herbert Hoover realized. He spent much of his life attempting to apply these values and to teach us what he learned. If you examine the record of what he did and what he said, you will find that he speaks to us still. 
Copyright of Annals of Iowa is the property of State of Iowa, by \& through the State Historical Society of Iowa and its content may not be copied or emailed to multiple sites or posted to a listserv without the copyright holder's express written permission. However, users may print, download, or email articles for individual use. 